\title{
An anomalous White Mullet, Mugil curema (Perciformes: Mugilidae), with three ovarian lobes found in the Gulf of Cariaco, Venezuela
}

\author{
A.K. Bashirullah ${ }^{1}$, E.H. Williams, Jr. ${ }^{2}$ \& L. Bunkley-Williams ${ }^{3}$ \\ 1 Instituto Oceanográfico, Universidad Oriente, Apartado 94, Cumaná 6101, Venezuela \\ 2 Caribbean Aquatic Animal Health Project, Department of Marine Sciences, University of Puerto Rico, P.O. Box 9013, \\ Mayagüez, Puerto Rico 00861-9013; ewilliams@uprm.edu \\ 3 Department of Biology, University of Puerto Rico, P.O. Box 9012, Mayagüez, Puerto Rico 00861-9012 lwilliams@ \\ uprm.edu \\ Corresponding author; bashiru@re.udo.edu.ve
}

Received 15-VII-2007. C Corrected 01-XI-2007. Accepted 13-II-2008.

\begin{abstract}
One White Mullet, Mugil curema Valenciennes (Perciformes: Mugilidae), out of 386 examined from the Gulf of Cariaco, Venezuela in 1984-1985, had a complete third lobe in the ovary. The mullet was $24.8 \mathrm{~cm}$ in standard length and weighed 280 grams. The two halves of the doubled ovarian lobe were separated by a thick, fibrous septum and contained atretic ova. The atretic ova had grotesque shapes and were undergoing liquefaction and elicited macrophages. Most of the ova appear to have been retained due to a distal obstruction. There was no evidence of a neoplasm. It may possibly be related to increasing levels of pollution in the Gulf. No similar anomaly has ever been reported in a fish. Rev. Biol. Trop. 56 (Suppl. 1): 285-288. Epub 2008 May 30.
\end{abstract}

Key words: unique anomaly, pollution effect, triple ovarian lobes, Mugil cephalus, Mugil curema, Mugilidae.

The White Mullet, Mugil curema Valenciennes, (family Mugilidae) is a common and important food fish in the Caribbean (Carpenter 2002). It occurs throughout the Western Atlantic and is found in the Eastern Atlantic and Eastern Pacific (Froese and Pauly 2007). This fish reputedly attains a total length (TL) of $91 \mathrm{~cm}$, but is most commonly found 35 cm TL or less (Carpenter 2002).

Ovarian anomalies have been reported in another mugil species, the Striped Mullet, Mugil cephalus Linnaeus, 1758 (Heldt 1948), and in a variety of other fishes (as summarized by Dawson 1964, 1971). Franks et al. (1998) found four gonadal lobes in a Striped Mullet in the northern Gulf of Mexico, but these represented the hermaphrodic expression of testicular and ovarian lobes.

We found a White Mullet in the Gulf of Cariaco, Venezuela, with a complete third lobe in the ovary. This condition, described below, has apparently not previously been recorded in fishes.

\section{MATERIALS AND METHODS}

In 1984 and 1985, the senior author conducted a survey and necropsy of 386 adult White Mullet from the Gulf of Cariaco, Venezuela. One specimen possessed an enlarged ovary that had three lobes. The specimen was transported to the laboratory in a plastic bag on ice in a cooler, photographed, and the mid-section of the body was excised and preserved in $10 \%$ neutral-buffered formalin within three hours of capture. The entire sample was sent to the Registry of Tumors in Lower Animals, Smithsonian Institution, Washington, District of Colombia, USA, for analysis as a possible tumor and histological slides of the mass were 
prepared and deposited (RTLA 7034). Standard paraffin embedding and hematoxylin and eosin stains were employed. Standard Length (SL) was taken from the tip of lower jaw to base of caudal fin.

\section{RESULTS}

The anomalous White Mullet was $24.8 \mathrm{~cm}$ in SL and weighed $280 \mathrm{gm}$. It was collected from San Antonio, Venezuela $\left(10^{\circ} 26^{\prime} 09^{\prime} \mathrm{N}\right.$, $\left.63^{\circ} 47^{\prime} 39^{\prime \prime} \mathrm{W}\right) 5$ January 1985 . This mullet possessed an enlarged ovary which had three lobes (Fig. 1). The left ovarian lobe appeared to be doubled into two lobes which were adhered together in a bulbous mass that was first thought to represent a tumor. The right lobe of the ovary appeared to be fully developed and of normal size and shape (Fig. 1).

The two halves of the doubled ovarian lobe were separated by a thick, fibrous septum and contained atretic ova. The atretic ova were grotesquely distorted and undergoing liquefaction and elicited macrophages. The septum was associated with empty follicles from spawned ova. This suggests that the septum could have formed as a result of the compression of empty follicles. The doubled lobe possessed only a single oviduct. There was no evidence of a proliferating cell type (i.e., neoplasm), instead most of the ova seem to have been retained due to a distal obstruction (J. C. Harshbarger, RTLA, pers. comm.).

\section{DISCUSSION}

The presence of a three-lobed ovary in only one of many hundreds of specimens examined indicates that this condition is rare in the White Mullet. This is based on the examination of several hundreds of female White Mullet from the Gulf of Cariaco and also analysis of White Mullet and their fisheries products from other regions.

A three-lobed ovary seems to be a unique occurrence in fishes as this condition was not mentioned in articles summarized by Dawson (1964, 1966, 1971), Hickey (1972), or Dawson

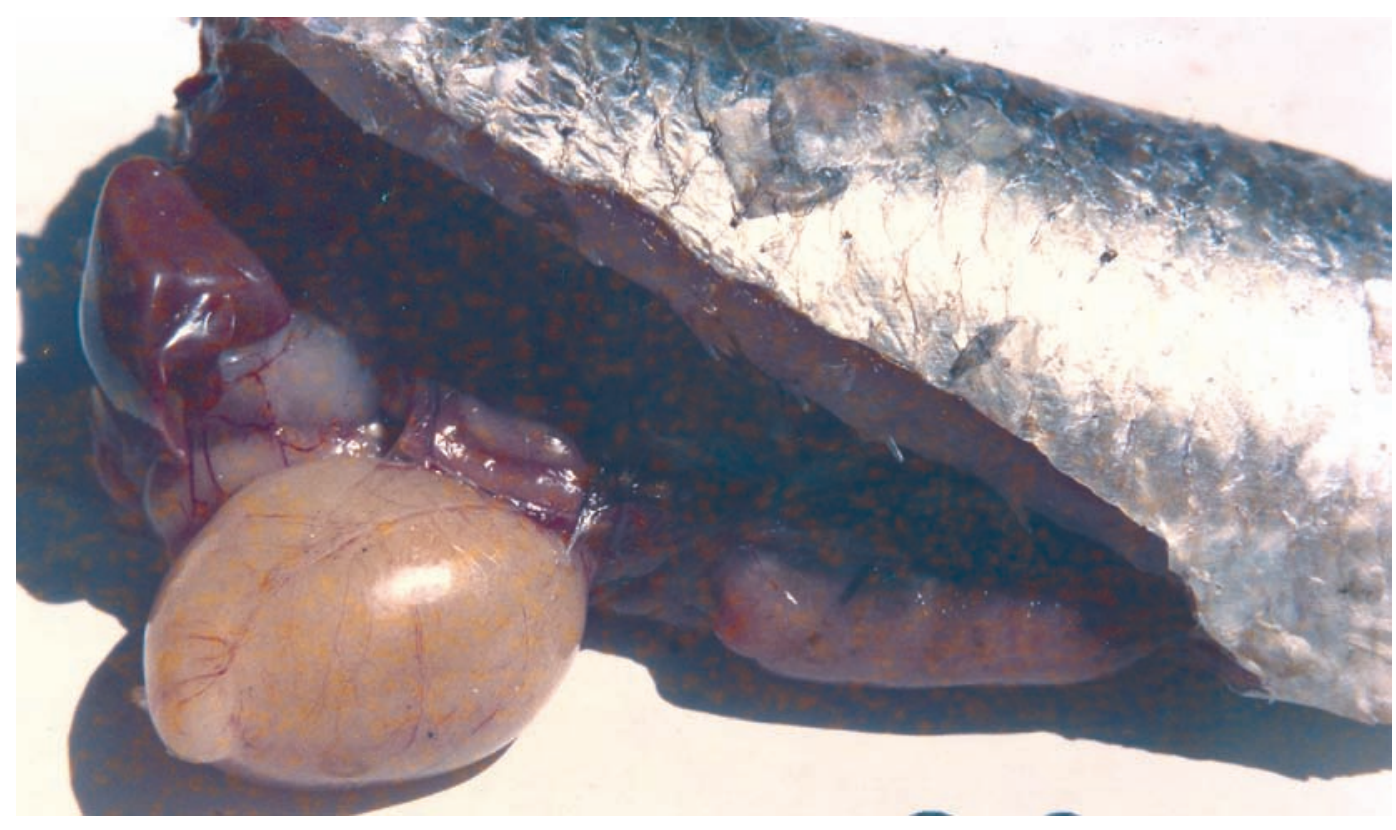

Fig. 1. Mid-body segment of a White Mullet, Mugil curema Valenciennes, $24.8 \mathrm{~cm}$ in Standard Length and weighing 280 gm collected from San Antonio, Venezuela, 5 January 1985. Abdominal cavity opened to expose a bulbous mass in the lower left that is two lobes of the ovary adhered together. Elongate structure in lower right is a normal lobe of the ovary. 
and Heal (1976). The Paperna and Overstreet (1981) monograph on the diseases and anomalies of mullets did not mention this condition. The only other anomaly in the White Mullet that we are aware of was a swim bladder extruding through the body wall reported by Kroger and Guthrie (1973). Arias de Díaz et al. (2001) reported anomalies involving the size of the heads of White Mullet in the Gulf of Cariaco, but these reports were based on undocumented information from fishermen. Other ovarian anomalies have been reported in the Striped Mullet (Heldt 1948), and in a variety of other fishes (as summarized by Dawson 1964, 1971). Franks et al. (1998) found four gonadal lobes in a Striped Mullet in the northern Gulf of Mexico, but half of those were testicular.

Easa et al. (1989) described a hypodermal lipoma in a Striped Mullet from Egypt. A number of authors have found wart-like tumors histologically resembling fibromas in Striped Mullet along the Atlantic and Gulf Coasts of the USA (as summarized by Sindermann 1990). Edwards and Overstreet (1976) suggested that increasing levels of pollution in the Gulf of Mexico may be causing increases in the number of these tumors in Striped Mullet. Arias de Díaz et al. (2001) found high levels of vanadium in the gonads of White Mullet in the Gulf of Cariaco, which they considered indicative of general water pollution. The Cariaco Basin is the largest natural anoxic basin in the world and its microbial communities may be having a negative effect on fishes (Madrid et al. 2001). Toxic dinoflagellate blooms also occur in the Gulf (Ferraz-Reyes et al. 1979). We participated in a conference about toxic dinoflagellate blooms and fish kills in Cumaná, Venezuela, in 1992 (conference proceedings were never published). During a parasite survey of commercial fishes in western Venezuela conducted by the present authors in June and July 1999, tumors were found in two other species of fishes in the Gulf of Cariaco (Williams and Bunkley-Williams 2007). The ovarian anomaly reported here involving the White Mullet, the anomalies in this fish reported by Arias de Díaz et al. (2001), and the presence of tumors in other Gulf fishes are conceivably related to increasing pollution levels in the Gulf of Cariaco (Arias de Díaz 1997, Williams et al. 2007).

\section{ACKNOWLEDGMENTS}

We thank John C. Harshbarger, RTLA, for analyzing the sample for possible tumors; and Peter Rocafort for improving and printing the photograph.

\section{RESUMEN}

Una lisa blanca, Mugil curema Valenciennes (Perciformes: Mugilidae), de 386 que fueron examinadas en el Golfo de Cariaco, Venezuela, entre 1984 y 1985, tenía un tercer lóbulo completo en el ovario. El pez medía $24.8 \mathrm{~cm}$ de largo y pesaba 280 gramos. Las dos mitades del lóbulo doble del ovario estaban separadas por un septo grueso y fibroso y contenían óvulos atrésicos. Los óvulos atrésicos tenían formas grotescas y estaban sufriendo liquefacción y produciendo macrófagos. La mayoría de los óvulos parecían haber sido retenidos por una obstrucción distal. No se encontró evidencia de neoplasma. Este fenómeno puede estar relacionado con el aumento en los niveles de contaminación del Golfo. Ninguna anomalía similar a la descrita anteriormente ha sido reportada en un pez.

Palabras clave: anomalía única, contaminación - efecto, lóbulos triples de ovario, Mugil cephalus, Mugilidae.

\section{REFERENCES}

Arias de Díaz, A. 1997. Pesticides residues in two localities of the Cariaco Gulf. Venezuela. Special Bull., IOV: 87 (Summary).

Arias de Díaz, A., N. Gamboa \& J. García. 2001. Vanadium levels in gonads of White Mullet (Mugil curema) in the Cariaco Gulf, Venezuela. Zootec. Trop. 19: 165-172.

Carpenter, K.E. (Ed.). 2002. FAO species identification guide for fishery purposes. The living marine resources of the Western Central Atlantic. Vol. 3: Bony fishes part 1 (Acipenseridae to Grammatidae), FAO, Rome; 1373 p.

Dawson, C.E. 1964, 1966, 1971. A bibliography of anomalies in fishes. Gulf Res. Repts. 1:308-399; Suppl.1, 2:169-239; Suppl. 2, 3: 215-239. 
Dawson, C.E. \& E. Heal. 1976. A bibliography of anomalies in fishes. Gulf Res. Repts. Suppl. 3, 5: 35-41.

Edwards, R.H. \& R.M. Overstreet. 1976. Mesenchymal tumours of some estuarine fishes of the northern Gulf of Mexico. I. Subcutaneous tumours, probably fibrosarcomas, in the striped mullet, Mugil cephalus. Bull. Mar. Sci. 26: 33-40.

Ferraz-Reyes, E., G. Reyes-Vasquez \& I.B. Bruzual. 1979. Dinoflagellate blooms in the Gulf of Cariaco, Venezuela. p. 155-160 In: Taylor and Seliger (eds.) Toxic dinoflagellate blooms. Elsevier/North Holland, New York, New York, USA.

Franks, J.S., N.J. Brown-Peterson, D.P. Wilson, R.J. Russell \& J.K. Welker. 1998. Occurrence of a synchronous hermaphroditic Striped Mullet, Mugil cephalus, from the northern Gulf of Mexico. Gulf Res. Repts. 10: 33-40

Heldt, H. 1948. Sur des cas curieux de malformatons d'ovaries chez Mugil cephalus Cuvier. Bull. Soc. Sci. Nat. Tunis 1: 34-35.

Hickey, C.R., Jr. 1972. Common abnormalities in fishes, their causes and effects. New York Ocean Sci. Lab. Rep. 13: 20 p.
Kroger, R.L. \& J.F. Guthrie. 1973. Additional anomalous menhaden and other fishes. Chesapeake Sci. 14: 112-116.

Madrid, V., G. Taylor, M. Scranton \& A. Chistoserdov. 2001. Characterization of bacterial communities in the anoxic zone of the Cariaco Basin. Appl. Environ. Microbiol. 67: 1663-1674.

Paperna, I. \& R.M. Overstreet. 1981. Parasites and diseases of mullets (Mugilidae). Chapter 13, p. 411-493. In: Oren, O.H. (ed.) Aquaculture of grey mullets. International Biology Program 26, Cambridge University, Cambridge, Great Britain.

Sindermann, C.J. 1990. Principal Diseases of Marine Fish and Shellfish. Academic , San Diego, California, USA.

Williams, E.H., Jr., L. Bunkley-Williams, and A.K.M. Bashirullah. 2007. Tumors and anomalies of Venezuelan fishes. Proc. Assoc. Mar. Lab. Carib. 33: 93.

\section{INTERNET REFERENCE}

Froese, R. \& D. Pauly. Editors. 2007. FishBase. World Wide Web electronic publication. www.fishbase.org, version (08/2007). 